\title{
Diameter Surveys of the Inner Cylinder of the CC Cryostat
}

Engineering Note \#3740.214-EN-118

Issued: October 16, 1987

Originator: Richard D. Luther 


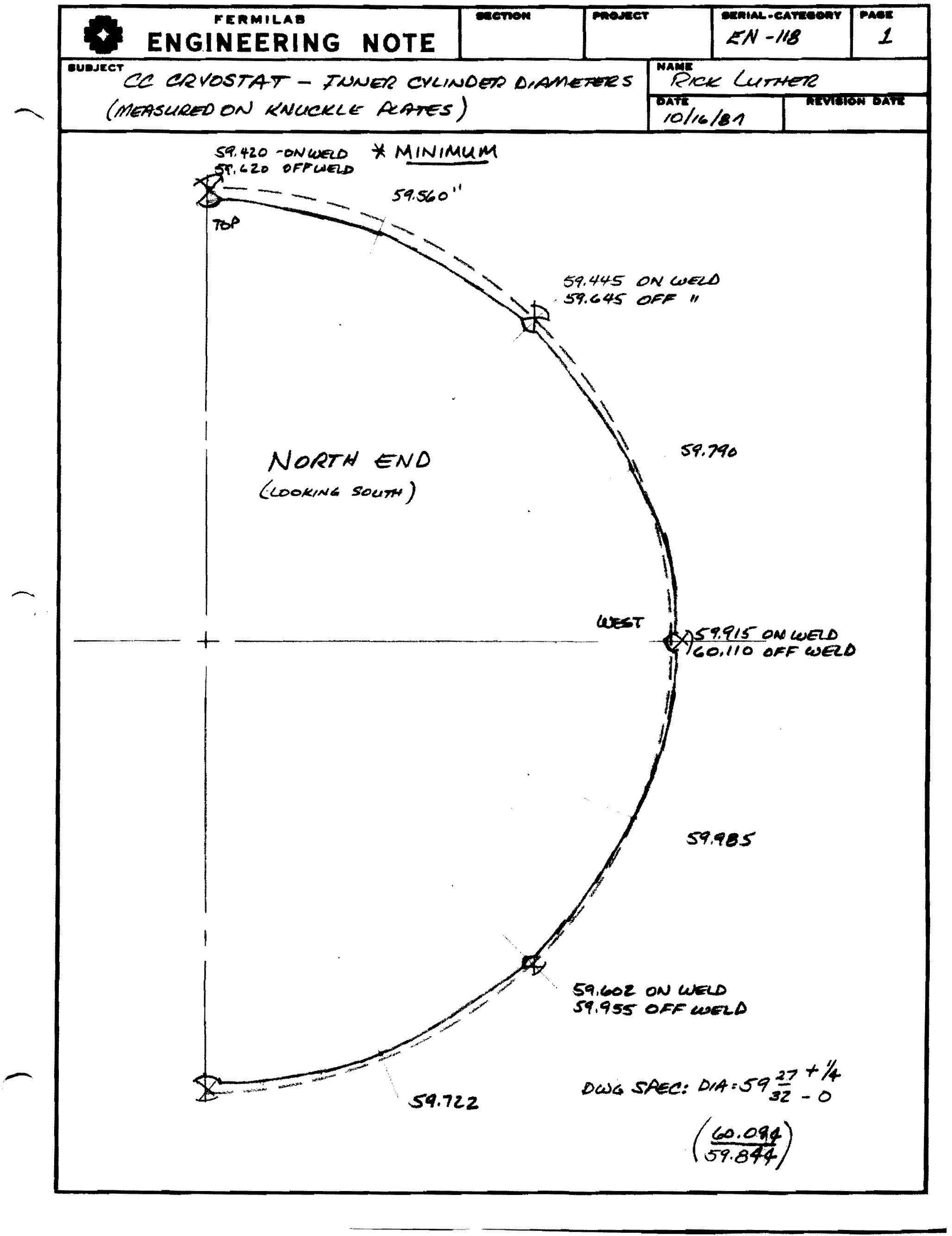




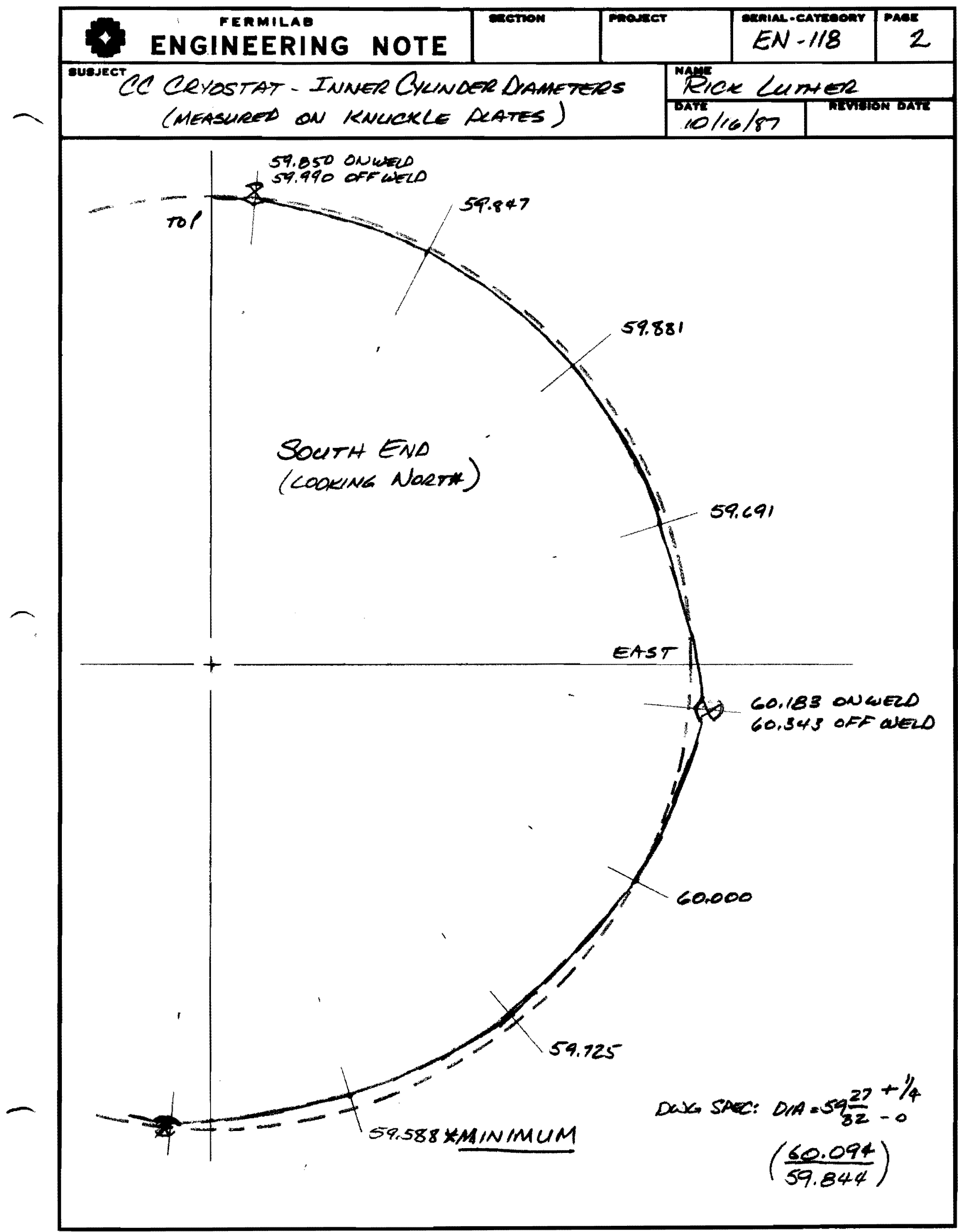

